\title{
Regional Innovation System in Rural Economic Institutions: Empirical Evidence From Semarang, Indonesia
}

\author{
Edy Dwi Kurniati ${ }^{* *}$, Indah Susilowati ${ }^{2}$, Suharno ${ }^{3}$ \\ ${ }^{1}$ Faculty of Economics and Business, Universitas Darul Ulum Islamic Centre Sudirman GUPPI \\ (UNDARIS) Semarang, Indonesia, \\ ${ }^{2}$ Faculty of Economics and Business, Univeristas Diponegoro Semarang, Indonesia, E-mail: \\ indahsusilowati@undip.ac.id \\ ${ }^{3}$ Faculty of Economics and Business, Universitas Jenderal Soedirman Purwokerto, Indonesia, \\ Corresponding Author: kurni_edy@yahoo.co.id
}

Recieved: October 2018 | Revised: March 2019 | Accepted April 2019

\begin{abstract}
This study aims to analyze the factors that influence the innovation capacity of the rural economic institution and its impact on Institution performance.Research was conducted by interviewing 111 managers of rural economic institutions in Semarang regency, Indonesia. Factors of policy and regulation, development of innovation infrastructure, assistance and integration of knowledge were used to analyze the role of the Government and Higher Education in the village innovation system. The Institution management and innovation culture capacity factors were used to analyze the role of rural economic institutions. Policy and regulatory factors, innovation infrastructure, management capacity, assistance capacity, innovation culture and knowledge integration were measured based on the preference of the rural economic institution manager. The qualitative model was examined through an empirical analysis to fulfill the proposed aim of the research.The results of the study showed that: the influential factors on the innovation capacity in rural areas were policy and regulation support, innovation infrastructure, management capacity, innovation culture and knowledge transfer. Innovation Capacity had a positive impact on Institution performance. The implication of this study highlighted the importance of strengthening Institution and knowledge-based rural economic organizations which was integrated among stakeholders as actors in the rural innovation system.
\end{abstract}

Keywords: regional innovation system, rural economic institution JEL Classification: 031

How to Cite: Kurniati, E., Susilowati, I., \& Suharno, S. (2019). Regional Innovation System in Rural Economic Institutional: Empirical Evidence From Semarang, Indonesia. Jurnal Ekonomi Pembangunan: Kajian Masalah Ekonomi dan Pembangunan, 20(1). doi:https://doi.org/10.23917/jep. v20i1.7040

DOI: https://doi.org/10.23917/jep.v20i1.7040

\section{Introduction}

Innovation is an important aspect for economic growth. Based on the SchumpeterianKirznerian Theory (Croitoru, 2012; Stuetzer, 2017), entrepreneurial behavior creates and captures new opportunities for growth. Innovation is not only done at the individual and organizational level but also at the system level. Innovation system which promotes knowledge-based economy, has been realized by 
many countries to improve national or regional competitiveness (Kurniati, Dian, \& Prajanti, 2018; Kusharsanto \& Handayani, 2017; Santos \& Simões, 2014). The attention to the Regional Innovation System has grown significantly over the past three decades driven by interest in innovation as a source of competitive advantage, and the need for policies to address regional inequality (Asheim, Smith, \& Oughton, 2011). Innovation has become an important part of regional policy in Indonesia the last three decades, but the Regional Innovation System in rural areas has yet shown to be executed in a consistent, systematic and neat fashion (Brillyanes \& Wilopo, 2018).

The Rural Innovation System Program (RISP) (Sumpeno et al., 2013) is one of the strategies in national innovation system that embodies the process of interaction between the strengthening components of the innovation system in rural areas. Each village must conduct some important actions to strengthen RISP, i.e. creating a policy to establish coordination team and RISP Roadmap, structuring RISP in the area of both institutions and RISP resources, developing RISP through local potential, and coordinating and reporting to the central government. The Regional Innovation System requires the collaboration of all stakeholders both individuals and institutions and communities in the economy (industry) sectors, governments and universities (Kusharsanto \& Handayani, 2017).

Semarang Regency is one of the regions in Central Java Province, Indonesia; economic growth of which is supported by the leading sectors of industry, agriculture and tourism (Bappeda, 2018): 1). Most villagers (72.6\%) live in the agricultural and industrial sectors (BPS, 2016). The agricultural sector, processing industry and services are the leading sectors of Semarang Regency to compete in the global era (Bappeda, 2018). The development of the agricultural and industrial sectors in the countryside is one of the strategies to compete in the global era based on local wisdom. Rural areas provide not only basic natural resources, but also the source of local wisdom (Brillyanes \& Wilopo, 2018). Rural development aims to improve the quality of human life and to alleviate the poverty through the provision of basic needs, the construction of facilities and infrastructure, the development of potential of local economy, and the sustainable use of natural and environmental resources, by promoting togetherness, kinship and mutual cooperation (Pyburn \& Woodhill, 2014). However, in rural areas, natural resources and agricultural land are increasingly limited along with population growth (Kurniati, 2013), so that innovation in rural areas is needed in such dynamically changing environmental conditions.

In the free markets era, SMEs in agricultural sectors, industries sectors, distributions and others sectors that are mostly in rural areas have difficulty competing due to economic scale factors and limitations in accessing resources (Royer, Bijman, \& Bitzer, 2016). Based on New Institutional Economic Theory (NIE) (Williamson, 2015), development of the economic sector in rural areas can be done through institutional arrangements (micro level) and institutional environment (macro level). In the micro level, SMEs in rural areal can collaborate by: forming institutions (which are based on contracts, vertical and horizontal organizations, and partnerships), increasing governance in accessing resources (raw materials, information and market, finance, technology and innovation), increasing economic scale so that they have the ability to compete in the free market era (Brillyanes \& Wilopo, 2018; Kurniati, 2013; Kurniati et al., 2018). In macro level, development of the economic sector in the countryside can be done through the function of regulation and rule of the system to reduce the lack of conventional economy.

The success of the Rural Innovation System Program is influenced by: policy and regulation, innovation infrastructure, Institution capacity 
and culture of innovation (BPPT, 2013). From the regulation perspective, government has strived for providing incentives for innovation conducts, but the problem is that there is no legal guarantee for violations of Intellectual Property Rights. In terms of infrastructure, guidelines for village innovation, innovation grants, assistance, innovation / appropriate technology exchanges are available for facilitating innovators (at the level of economic institutions) to undertake rural innovation activities. However, many rural areas in many developing countries have a weak Institution capacity, a low culture of innovation and entrepreneurship, and tend to be resistant to the change (Royer et al., 2016). Various policies and regulations, the development of innovation infrastructure (guidelines, applications, IT), Institution capacity (training) and culture of innovation (empowerment) have been carried out by the government, but innovation activities at the rural institutions level (such as: Bumdes, Gapoktan) have not been optimal. This is because, in general, administrators of economic institutions in rural areas have low education, are not accustomed to accessing to information except that of from village officials, agricultural extension agents, and marketers.

In terms of infrastructure, the use of information technology has reached rural areas, however knowledge transfer activities that facilitate innovators have not been optimal. Innovators at the level of economic institutions in rural areas need a knowledge transfersystem that accommodates them in carrying out innovation activities, such as in: choosing effective technologies, innovation-based problem solving, applications for composing innovation proposals, report on the use of funds which is connected with stakeholders (such as : escort agencies, government institutions, financial institutions, insurance institutions).
Innovative infrastructure support significantly lowers transaction costs and supports access to innovation activities (Barrett, 2008). Infrastructure is important, especially for farmers, industrial actors and rural institutions, to produce high quality products. That is because a poor infrastructure may cause problems of the decrease in quality and access to input resources and markets (Royer et al., 2016). In complex and dynamic environments, integrated knowledge resources become increasingly important. Internet and information technology have a major impact on serving business units or organizations to develop rapidly through information-driven, customer-centric, e-oriented and co-creation (Burke \& Ng, 2006).

Entrepreneurship works on innovation activities which disrupts economic balance and creates opportunities (SchumpeterianKirznerian Theory) (Croitoru, 2012; Stuetzer, 2017). An innovation is a new product, process, service management approach that is adopted on a significant scale because it is useful. It may solve a problem, increase efficiency, meet consumer demands, or open up whole new ways of doing things. Rural innovation has a number of dimensions - social, technical, organizational and Institution and can take different shapes and forms. Rural innovation system A network of individuals, organizations and enterprises focused on bringing new products, processes and forms of organization into social and economic use, to achieving food and nutrition security, economic development and sustainable natural resource management. Entrepreneurship through an innovation process introduces new products, production methods, markets, supply sources, or industrial combinations that influence the economy going out of the previous equilibrium (Figure 1) (Verheul \& Thurik, 2001). 


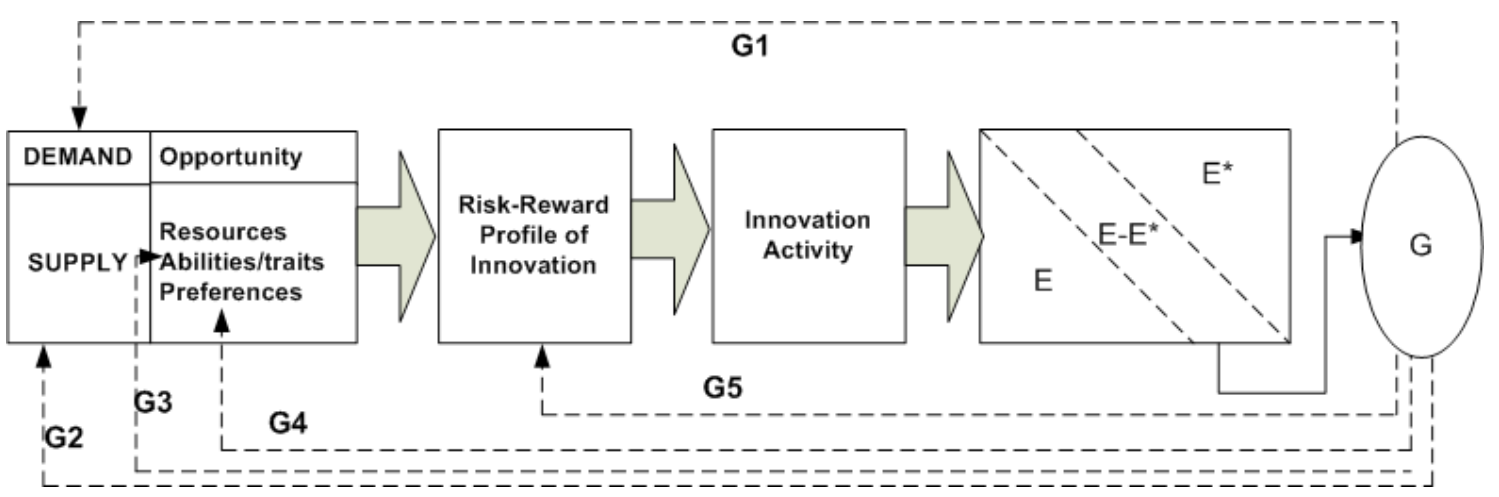

Source: developed from Verheul (2001)

Figure 1. Framework of Innovation Activity

Innovation activity is carried out by entrepreneurs to achieve equilibrium (E) or disequilibrium $\left(\mathrm{EE}^{*}\right)$. G is the government's effort to foster regional innovation through: 1) policy and regulation, 2) innovation infrastructure, 3) institution, 4) innovation culture. These are conducted correct disequilibrium (E-E*) so as to create economic growth.

1) Policy and Regulation. G1 is a government policy that encourages the growth of innovation activities in certain areas, seen from the demand of innovation such as tax incentives and export convenience. G5 is a government policy to develop regional innovation activity through macro policies such as: fiscal incentive policy, subsidy, protection policy for Intellectual Property Rights, and rules for guaranteeing healthy business competition.

2) Innovation Infrastructure. G3 is a government policy to develop existing regional innovation activity through the provision of information technology infrastructure, communication, knowledge transfer, guidance and counseling, and capital incentives to innovators, especially for small-scale businesses.

3) Institution. G2 is a government policy that stimulates the growth of innovation activity in certain areas in terms of the supply through Research and Development activities carried out by government agencies, agricultural counseling activities, education and training and Institution formation. Micro and small-scale businesses can cooperate such as by forming an institution (which is based on contracts, vertical and horizontal organizations and partnerships) for governance in accessing resources (raw materials, information and markets, finance, technology, innovation and design,), and increasing economic scale to make them more competitive in the free market era.

4) Innovation Culture. G4 is a government policy to develop regional innovation activity by raising awareness through education and mass media. This policy is employed to improve the low culture of innovation and entrepreneurship in an area. Generally, rural areas are rich in local wisdom as a basis for sustainable development, but tend to be resistance of change. Whereas the environment changes dynamically, while natural resources in rural areas are increasingly limited.

Brillyanes and Wilopo (Brillyanes \& Wilopo, 2018) in their study in East Java Indonesia found that the Rural Innovation System as a strategy to reduce poverty has not shown to be consistently executed systematically and neatly across the region. Budiarto and Bachrudin (Budiarto \& Bachrudin, 2018) identified inhibiting factors to determine the strengthening of the Regional Innovation System. The inhibiting factors include: Structure barrier value, Innovation of the environment, supporting research and development, Human resources and Infrastructure. The structural barriers are the main determining factor in implementing Regional Innovation System, which shows there is a poor synergy between stakeholders, lack of commitment to Regional Innovation System. The 
innovative environmental is low because there is no collaboration between all innovation actors, lack of interest in innovation and uncertainty in economic outcomes, absence of brands that form regional clusters, inability to benefits from cooperative combinations. Low human resource capacity and innovation infrastructure support are also obstacles in innovation activities. The role of localized learning is strategic and important in the promoting regional development, especially in rural areas (Santos \& Simões, 2014).

\section{Research Method}

This research was conducted on economic institutions in rural areas in Semarang Regency, Central Java, Indonesia. Semarang Regency is one of the regions in Central Java Province of Indonesia, with economic growth supported by leading agricultural sectors, processing industries and services. Most of the population (73\%) lives from agricultural sector and industrial SMEs in rural areas. Economic institution in rural areas includes Bumdes, Gapoktan PUAP and Agricultural Cooperatives. Primary data were collected through direct interviews with 111institution managers based on a list of prepared questions. Meanwhile, secondary data were obtained from the literature, institutions, and agencies related to this research. The sampling of institution managers uses simple random sampling because the population is tend to be homogeny.

Table 1: Variable and Operational Definition

\begin{tabular}{|c|c|c|}
\hline Variables & Indicators & Scale \\
\hline $\begin{array}{l}\text { Institution } \\
\text { Performance (Y) }\end{array}$ & Asset accumulation (\%) & Continum (\%) \\
\hline $\begin{array}{l}\text { Innovation Capacity } \\
\text { (INOV) }\end{array}$ & $\begin{array}{l}\text { 1. Product and service innovation } \\
\text { 2. Process innovations }\end{array}$ & $\begin{array}{l}(1=\text { not available, } 2 \\
=\text { available, } 3=\text { high } \\
\text { available })\end{array}$ \\
\hline $\begin{array}{l}\text { Policy and } \\
\text { Regulation (REG) }\end{array}$ & $\begin{array}{l}\text { 1. Fiscal incentives } \\
\text { 2. Property Right Protection policy } \\
\text { 3. Warranty of healthy business competition }\end{array}$ & $\begin{array}{l}(1=\text { not support, } 2 \\
=\text { support, } 3=\text { high } \\
\text { support })\end{array}$ \\
\hline $\begin{array}{l}\text { Innovation } \\
\text { Infrastructure (INF) }\end{array}$ & $\begin{array}{l}\text { 1. Access to Financial Support } \\
\text { 2. The level of use of ICT in rural areas } \\
\text { 3. Condition of ICT infrastructure in rural areas } \\
\text { 4. HR training }\end{array}$ & $\begin{array}{l}(1=\text { not support, } 2 \\
=\text { support, } 3=\text { high } \\
\text { support) }\end{array}$ \\
\hline $\begin{array}{l}\text { Institution Capacity } \\
\text { (MAN) }\end{array}$ & $\begin{array}{l}\text { 1. Capacity of Innovation adoption } \\
\text { 2. Capacity of Cooperation with Suppliers } \\
\text { 3. Capacity of Cooperation with Buyer } \\
\text { 4. Capacity of Cooperation with Competitors }\end{array}$ & $\begin{array}{l}(1=\text { not good, } 2= \\
\text { good, } 3=\text { very good })\end{array}$ \\
\hline $\begin{array}{l}\text { Innovation Culture } \\
\text { (CUL) }\end{array}$ & $\begin{array}{l}\text { 1. Innovation Culture } \\
\text { 2. Entrepreneurial culture } \\
\text { 3. Concern for traditional knowledge }\end{array}$ & $\begin{array}{l}(1=\text { not good, } 2= \\
\text { good, } 3=\text { very good })\end{array}$ \\
\hline $\begin{array}{l}\text { Knowledge } \\
\text { Transfer(KM) }\end{array}$ & $\begin{array}{l}\text { 1. Access to Innovation } \\
\text { 2. Access to Information on Innovation Funding } \\
\text { 3. Access to Information Reporting } \\
\text { 4. Connected with stakeholders }\end{array}$ & $\begin{array}{l}(1=\text { not good, } 2= \\
\text { good, } 3=\text { very good })\end{array}$ \\
\hline
\end{tabular}


The analysis method in this study used a multilevel regression analysis model, that is, the least squares regression with the following equation:

$\mathrm{INOV}=B_{0}+B_{1} \mathrm{REG}+B_{2} \mathrm{INF}+B_{3} \mathrm{MAN}+B_{4} \mathrm{CUL}$ $+\beta_{6} \mathrm{KM}+\varepsilon 1$

$\mathrm{Y}=\delta_{0}+\delta_{1} \mathrm{INOV}+\varepsilon 2$

Where a, B: intercept and slope, $\varepsilon$ : Error. To evaluate the accuracy of regression function toward observation value can be seen from the value of goodness fit. The statistic of goodness of fit is measured from $\mathrm{F}$ statistic value and determination coefficient. The determination coefficient $\left(R^{2}\right)$ is used to decide percentage deviation of dependent variable that is caused by independent variable. The test of $\mathrm{F}$ is the formula significance test that is used to determine how independent variable affects the dependent variable (Y). P-valueis the probability to refute zero hypotheses if the test is presumably correct. The significant level is $1 \%$ (very significant), $5 \%$ (significant) and $10 \%$ (moderate significant). If $\mathrm{p}$ value is less than significant level, the researcher will conclude that the observed influence depicts the population characteristic not only the error sampling.

\section{Results and Discussion 3.1 Results}

The average accumulation of assets in Economic Institutions in rural areas in Semarang Regency was $37 \%$ compared to the initial capital. The initial capital itself came from the government and self-help capital. Innovation Capacity of rural economic institutions in general was low (mean $=2.21$ ). In general, economic institutions in rural areas in Semarang Regency have low capacity in product/service innovation (average $=1.23$ ) and process innovations (average $=1.19$ ). Innovation capacity consisted of product and service innovation and process innovation. Product innovation included management of coffee commodities, agro tourism, and waste management for economic value. Process innovation, then, encompassed some aspects such as price control, product quality control, packaging, post-harvest technology adoption, and marketing innovation.

As for the policy and regulation, the average respondent's perception of policies and regulations is supportive (on average $=1.92$ ). In terms of indicator, the average of respondent's perception of the fiscal incentives for innovation activities and warranty of healthy business competition is sufficiently supportive (average $=2.27$ and 2.23), however the respondent's perception of the protection policy of Intellectual Property Rights (IPR) is still low supportive (average $=1.25)$. The average respondent's perception of the availability of fiscal incentives is low, this can be caused there were already fiscal incentives for innovation activity, yet the absorption capacity of innovation grants was low. Fiscal incentives: Operational Funds for the Rural Knowledge and Innovation Program Activities, Operational Funds for Strengthening Technical Service Providers. Respondents' perception of the Intellectual Property Rights (HKI) protection policy was still low. Innovations made by individuals, companies, institutions were easily adopted without considering Intellectual Property Rights. The regulation concerning Intellectual Property Rights is actually available, but the implementation of law enforcement against violations of Intellectual Property Rights has not been supportive. 
Jurnal Ekonomi Pembangunan: Kajian Masalah Ekonomi dan Pembangunan, 20 (1), 2019, 108-129

Table2. Descriptive statistics

\begin{tabular}{|c|c|c|}
\hline Variables & MEAN & SD \\
\hline \multicolumn{3}{|l|}{ Institution Performance(Y) } \\
\hline Asset accumulation (\%) & 0.37 & 0.34 \\
\hline Innovation Capacity(INOV) & 1.21 & 0.49 \\
\hline Product and service innovation & 1.23 & 0.54 \\
\hline Process innovations & 1.19 & 0.48 \\
\hline Policy and Regulation(REG) & 1.92 & 0.44 \\
\hline Fiscal incentives & 2.27 & 0.49 \\
\hline Property Right Protection policy & 1.25 & 0.44 \\
\hline Warranty of healthy business competition & 2.23 & 0.49 \\
\hline Innovation Infrastructure(INOV) & 2.01 & 0.54 \\
\hline Access to Financial Support & 2.05 & 0.59 \\
\hline The level of use of ICT in rural areas & 2.05 & 0.61 \\
\hline Condition of ICT infrastructure in rural areas & 2.06 & 0.61 \\
\hline Facilitator Capacity & 1.91 & 0.63 \\
\hline HR training & 1.96 & 0.60 \\
\hline Institution Capacity(MAN) & 1.85 & 0.69 \\
\hline Capacity of Administration & 1.87 & 0.71 \\
\hline Capacity of Management & 1.90 & 0.74 \\
\hline Capacity of Governance & 1.77 & 0.72 \\
\hline Innovation Culture(MAR) & 1.99 & 0.52 \\
\hline Innovation Culture & 1.66 & 0.60 \\
\hline Entrepreneurial culture & 1.72 & 0.63 \\
\hline Concern for traditional knowledge & 2.59 & 0.49 \\
\hline Knowledge Transfer(KM) & 1.57 & 0.47 \\
\hline Access to Innovation & 1.59 & 0.49 \\
\hline Access to Information on Innovation Funding & 1.59 & 0.49 \\
\hline Access to Information and Market & 1.53 & 0.50 \\
\hline
\end{tabular}

Source: Analysed from interviewing managers of rural economic institutions (2017)

In terms of innovation infrastructure (INOV), in general the respondent's perception of the innovation infrastructure has supported (on average $=2.01$ ) both in the aspect of Access to Financial support, level of use of ICT in rural areas, condition of ICT infrastructure in rural areas, Facilitator Capacity and HR training. The rural Innovation Program (PID) is a program designed to encourage and facilitate the strengthening of village capacity oriented to meet the target of the RPJM Kemendesa PDTT-the priority program of the Village Official of PDTT, through raising rural productivity based on the development of entrepreneurship, improving the quality of human resources (HR) and fulfilling and increasing rural infrastructure. In connection with the capacity of innovation infrastructure, generally there have been guidelines for rural innovation, innovation grant funds, assistance, innovation / appropriate technology exchanges facilitating innovators (at the level of economic institutions) to conduct rural innovation activity. Recently, information technology infrastructure has reached remote villages in Semarang Regency, but the development of information and communication technology in rural areas has not been used optimally. Training has also been conducted to

114 Jurnal Ekonomi Pembangunan, ISSN 1411-6081, E-ISSN 2460-9331 
improve the entrepreneurial capacity of Institution administrators in rural areas. In coaching and controlling the PID, government is assisted by professional assistants. In accordance with Government Regulation No. 47 of 2015 concerning Amendments to Government Regulation No. 43 of 2014 about Regulation of the Implementation of Law Number 6 of 2014 concerning Villages and the Regulation of the Village Officials, Development of Disadvantaged Regions and Transmigration No. 3 of 2014 concerning Village Facilitators who also explains the position of Experts at the District level as Professional Assistants in helping facilitate village development and empowerment. The Directorate General of Development and Empowerment of Rural Community, the Village Officials, Development of Disadvantaged Areas and Transmigration stipulates and issues Administrative-Operational Standards and Procedures (OSP) and PID Assistance Reporting. Such an OSP contains the main issues related to the implementation of the Rural Innovation Program Assistance through efforts made by the Government, Provincial Government, District / City Government, Third Party or Rural community participation. It is also used as a means to help ensure transparency and accountability in the implementation of the Rural Innovation Program so that it can reflect the governance of rural development and empowerment that is intertwined to the Self Governing Community. Despite the availability of regulations, Operational Standards and Procedures, however the results of the study found that the facilitators capacity was inadequate (average $=1.91$ ). This is because it is not easy to find a companion capacity for village institutions with agricultural environmental characteristics, complex markets. The challenge of facilitators village institutions is more complex than the role in empowering farmers as individuals or farmer groups (only production focus). The companion must have marketing and networking capacity, quality management and farm risk management, but on the other hand the background that has never been an entrepreneur or manager in an agricultural business is an obstacle in that role.
In terms of Institution capacity, the rural institutions tended to have low management and governance capacity (mean=1,87). Management of rural institutions capacity was low in aspects of: administration capacity (mean $=1,80$ ), management capacity (mean $=1,77$ ) andgovernance capacity (rata-rata $=$ 1,77).Rural institutions such as Gapoktan and Bumdes were born in the era of free trade and changes in the agricultural environment and dynamic markets, while the rural environment in general is still traditional. Rural institution, like any other socio-economic organizations in rural areas are usually still managed traditionally such as, lack of administrative records because they are not accustomed to developing organizational accountability reports, are not familiar with work plans, are based on centralized decisions on the role of local leaders and are lack of member participation. Furthermore, agriculture is production-oriented in nature or is performed as what exactly done from one generation to another. It is not marketoriented and has not been integrated between upstream and downstream businesses; the actors are used to being dependant (on Government funding assistance, the information, knowledge and experience of the elder or agricultural counselor). These cause the image that rural institutions are just similar to other organizations such as farmer groups, arisan groups, that is, the organizations which focus on providing assistance and have not created an entrepreneurial culture, Gapoktan and Bumdes, as farmer institutions is a more complex organization than other ones in rural communities (such as: farmer groups, arisan groups, arts groups and other social and religious organizations). Gapoktan includes various business units, not only agricultural production, but also is expected to be developed to have (Ministry of Agriculture, 2007): marketing business units, capital business units, management of production inputs, agricultural product processing.

In terms of culture of innovation, innovation culture in the rural economic institutions in Semarang Regency in general are low (mean = 1.99). The rural economic institutions in Semarang Regency generally have a high level of awareness 
Jurnal Ekonomi Pembangunan: Kajian Masalah Ekonomi dan Pembangunan, 20 (1), 2019, 108-129

of traditional knowledge (average $=2.59$ ). Rural areas in Semarang Regency had many sources of local wisdom, such as: culture of helping each other, mutual cooperation, prioritizing public interests rather than those of personal and community (talk less do moresepi ing pamrih, rame ing gawe), and resource management which was environmentally friendly. However, they tended to be resistance of change. Entrepreneurial culture in rural communities in Semarang district was commonly low. On the other hand, farmers / groups were likely to be dependant (relying on government funding assistance, the information, and the knowledge and experience of the elder or agricultural counselor). Regarding the level of concern for traditional knowledge, knowledge of local wisdom was a unique knowledge resource, and valuable for it was not easily replicable and irreplaceable; not only it was a source of competitive advantage but also often provided wisdom in balanced and sustainable management of the environment (physically, socially, and spiritually).

In terms of knowledge transfercapacity, in general the respondents' perception of knowledge transfercapacity is still low (average $=1.57$ ) both in the aspects of knowledge transfer(acquisition, sharing and analysis) of the market, access to funding and adoption of appropriate technology.
In terms of infrastructure, the use of information technology has reached rural areas, however knowledge transferactivities have not been optimal. Innovators at the level of economic institutions in rural areas need a knowledge transfersystem that facilitates them in carrying out innovation activity, such as in: choosing effective technologies, problem solving-based innovation exchange, applications for developing innovation proposals, reporting on the use of funds which is connected with stakeholders (like institution facilitators, government institutions, financial institutions, and insurance institutions).

The result of the regression equation of the factors influencing the Innovation (Table 3) was proved through F-test value of 13.796 , with the level of significance at the error rate of $1 \%$. This result also showed simultaneously the factors in the model had a significant effect on the accumulation of assets. Based on the result of the regression equation, R2 value was 0.368 or $36.8 \%$ which reflected that all independent variables were able to explain the change variations, i.e. the increase or decrease in the dependent variable (accumulated assets of the institution) of $36.8 \%$, while the remaining, that was $63,2 \%$, was influenced by other variables excluded in this research model.

Table 3 The Regression Result

\begin{tabular}{lcccc}
\hline & \multicolumn{2}{c}{ Model 1 Innovation } & \multicolumn{2}{c}{ Model 2 Asset Accumulation } \\
\cline { 2 - 5 } (Constant) & $\beta$ & $\rho$ & $\delta$ & $\rho$ \\
INOV & -1.036 & 0.001 & -0.363 & 0.000 \\
REG & & & 0.605 & $* * *)$ \\
INF & 0.231 & $* *)$ & 0.047 & \\
MAN & 0.333 & $* * *)$ & 0.000 & \\
CUL & 0.109 & $* *)$ & 0.048 & \\
KNOW & 0.268 & $* * *)$ & 0.003 & \\
R-squared & 0.258 & $* *)$ & 0.014 & \\
F-statistic & 0.368 & & 0.795 \\
Prob(F-statistic) & 13.796 & & 427.692 \\
\hline
\end{tabular}

Source: Analysed from interviewing managers of rural economic institutions (2017)

Description: ${ }^{* * *}$ ) significantly impactful with error tolerance of $1 \% ; * *$ ) significantly impactful with error tolerance of $5 \%$ 
The regression result of the effect of Innovation capacity on performance (Table 3 ) was proved through F-test value was 427.692 , while the model is significant at an error rate of $1 \%$. These result also showed that simultaneously the factors in the model had a significant effect on the Institution Innovation Capacity. Meanwhile, the result of the regression equation showed the $\mathrm{R} 2$ value of 0,795 or $79,5 \%$ which reflected that all independent variables were able to explain the change variations i.e. the increase or decrease in the dependent variable (non-dependence of subsidies) of $79,5 \%$, while the remaining $(20,5 \%)$ was affected by other variables excluded in this research model.

Innovation Capacity (INOV) had a positive and significant impact on Institution performance $(\rho=0.000<1 \%)$. The regression coefficient of the Innovation Capacity on Institution performance was 0,605 .Interpretation ofregression coefficient that an increase in Innovation capacity of 1 unit would be accompanied by an increase in Institution performance of 0,605 percent, whereas Innovation Capacity decline as far as 1 unit would be accompanied by a reduction in Institution performance of 0,605 percent, noting that other variables remained constant.

Policy and Regulation (REG)had a positive and significant impact on innovation capacity $(\rho$ $=0.047<5 \%)$. The regression coefficient of the Policy and Regulation on innovation capacity was 0,231 .Interpretation of regression coefficient that an increase in Policy and Regulation of 1 unit would be accompanied by an increase in innovation capacity of 0,231 unit, whereas Policy and Regulation decline as far as 1 unit would be accompanied by a reduction in innovation capacity of 0,231 unit, noting that other variables remained constant.

Rural Infrastructure Capacity (INF) had a positive and significant impact on innovation capacity $(\rho=0.000<1 \%)$. The regression coefficient of the Rural Infrastructure Capacity on innovation capacity was 0,333.Interpretation of regression coefficient that an increase in Rural Infrastructure Capacityof 1 unit would be accompanied by an increase in innovation capacity of 0,333 unit, whereas Rural Infrastructure Capacitydecline as far as 1 unit would be accompanied by a reduction in innovation capacity of 0,333 unit, noting that other variables remained constant.

The capacity of Rural Institution Management (MAN) had a positive and significant effect on innovation capacity $(\rho=0.048<5 \%$ ). The regression coefficient of the Management Capacity on innovation capacity was 0,109. Interpretation of regression coefficient that an increase in Management Capacity of 1 unit would be accompanied by an increase in innovation capacity of 0,231 unit, whereas Management Capacity decline as far as 1 unit would be accompanied by a reduction in innovation capacity of 0,109 unit, noting that other variables remained constant.

Innovation culture (CUL) had a positive and significant effect on the capacity of innovation $(\rho$ $=0.003<1 \%$ ). The regression coefficient of the Innovation culture on innovation capacity was 0,268. Interpretation of regression coefficient that an increase in Innovation culture of 1 unit would be accompanied by an increase in innovation capacity of 0,268 unit, whereas Innovation culture decline as far as 1 unit would be accompanied by a reduction in innovation capacity of 0,258 unit, noting that other variables remained constant.

Knowledge transfer (KNOW) had a positive and significant effect on innovation capacity $(\rho=$ $0.014<5 \%$ ). The regression coefficient of the Knowledge transferon innovation capacity was 0,258.Interpretation of regression coefficient that an increase in Knowledge transferof 1 unit would be accompanied by an increase in innovation capacity of 0,258 unit, whereas Knowledge transferdecline as far as 1 unit would be accompanied by a reduction in innovation capacity of 0,258 unit, noting that other variables remained constant.

An important factors in the development of innovation systems in rural areas is Rural Innovation Infrastructure $(B=0.333)$, followed by Innovation culture $(B=0.268)$, Knowledge transfer $(B=0.258)$, Policy and Regulation (0.231) 
Jurnal Ekonomi Pembangunan: Kajian Masalah Ekonomi dan Pembangunan, 20 (1), 2019, 108-129

and Management capacity $((B=0.109)$. Increased Innovation Infrastructure, Innovation culture, Knowledge transfereach by $1 \%$ will effectively increase innovation capacity by $0.859 \%(0.333 \%$ $+0.268 \%+0.258 \%$ ), when other variables are constant. The role of infrastructure innovation, cultural aspect and knowledge transfer in supporting innovation activities in rural areas.

\subsection{Discussion}

Innovation activities are influenced by push and pull factors (Verheul \& Thurik, 2001). The innovation capacity in the system approach is influenced by structural barriers and opportunities (Santos \& Simões, 2014; Budiarto \& Bachrudin, 2018), policy and regulation support (Brillyanes \& Wilopo, 2018), innovation infrastructure (Budiarto \& Bachrudin, 2018), and human resource (Budiarto \& Bachrudin, 2018). Rural areas have different characteristics with urban and regional areas in general. This can affect the innovation system in rural areas. This study found that innovation culture and knowledge transfer is an important factor that influences rural innovation capacity, in addition to innovation infrastructure, policy and regulation support and human resources. The characteristics of innovation systems in rural areas that are influenced by the needs of innovation infrastructure. cultural and knowledge transfer.

Innovation Capacity had a positive and significant impact on Institution performance. Rural institutions both Bumdes, Gapoktan or Cooperatives are available for innovation activities such as: management of coffee commodities, agro-tourism management, water resource management, waste management for economic value, price control, product quality control, packaging, post-harvest technology adoption, marketing innovation generally have asset accumulation is higher than village institutions, either Bumdes, Gapoktan or Cooperatives, which are not available for innovation activities.

Policy and Regulation had a positive and significant impact on innovation capacity. Importance of Policies and Regulations in the development of innovation are also emphasized in the previous studies (Brillyanes \& Wilopo, 2018). Government policies and regulations play a role in increasing capacity and opportunity for economic institutional innovation activities in rural areas. Government policies and regulations in the form of fiscal incentives for innovation activities, protection of Intellectual Property Rights and Guarantees fair business competition has proven effective in increasing the innovation capacity of rural institutions, however the results of the study also found that regulation of Intellectual Property Rights still does not yet support, so these results have implications for strengthening law enforcement against violations of Intellectual Property Rights.

Rural Infrastructure Capacity had a positive and significant impact on innovation capacity. Village institutions that have access to adequate infrastructure capacity such as financial infrastructure, availability of information and communication technology, use of information and communication technology availability, adequate companion capacity and available training tend to have better capacity for innovation. Infrastructure support is needed to support access to input and output markets, access to credit information and facilities, and technical innovation assistance (Royer et al., 2016). On the input side, the availability of infrastructure supports access to resources, market information, financial services and technology. High quality input is an important prerequisite for achieving high product quality. Demand for inputs by business actors (farmers, fishermen, low traders and industrial entrepreneurs) is uncertain due to lack of liquidity and transactions for smallscale businesses. In addition, high input prices are combined with certainty the absence of output prices is an obstacle and inhibits smallscale business actors in rural areas to increase productivity and improve product quality to meet market needs (Kurniati et al., 2018). On the output side, the availability of infrastructure supports market information, quality control and inspection, and relations to the output market. 
The lack of market relations is often caused by rural infrastructure and the low production volume of individual farmers. Market networks are also hampered by monopolistic practices, corruption and low market confidence. In addition, the quality of agricultural and industrial products in rural areas is often uneven and uncertain, making private companies reluctant to cooperate with small-scale producers (Royer et al., 2016). Supermarkets often support large and mediumsized suppliers and are close to cities, considering the lower costs and risks of doing business with large and medium-scale suppliers in these rural areas. information such as relating to market demands, prices, class specifications, storage and transportation facilities is required, but the market information has not been managed optimally. Other constraints relate to a lack of product quality control. Access to certification, auditing, quality control and laboratory services may be important to verify these requirements. However, audit and certification of services is expensive because farmers have an inadequate economic scale (Royer et al., 2016). When individual businesses in rural areas have economies of scale efficiency and access to resources, the rural economic institutions have a role to improve constraints.

The capacity of Rural Institution Management had a positive and significant effect on innovation capacity. The result of the study found that Institution management capacity had a positive and significant effect on capacity for innovation. The results of this study support the previous studies (Budiarto \& Bachrudin, 2018) who found that Human Resources Management toward RIS was used as a reflection of the factors in the level of strengthening of RIS. The finding of significant influence of management capacity on innovation capacitycan be explained by Neoclassical Production Theory and Schumpeter's Theory which suggest the role of management and entrepreneurship in increasing production and markets. This shows that the higher the capacity of management, the more effective it will be in increasing the ability to manage resources (management capacity and entrepreneurship) aiming to raise the accumulation of Institution assets. Many institutions are built to strengthen the position of farmers in the economy, such as: the Association of Farmers' Groups (Gapoktan), and BUMdes. Yet, agricultural institutions and farmers themselves have not nailed their role in overcoming these problems. Some problems, such as ability in group organization, improvement or expansion of farms to the upstream and downstream sectors, marketing and cooperation in increasing bargaining position, inability to manage funds, inability to provide market information and to distribute / market / process the products, low management technical capacity, ability to cooperate, and lack of preparedness in the growth of autonomous businesses.

Generally, managers at rural / farmer institutions are selected based on their distinguished roles in society, older people who are respected by the community. They are usually accompanied by the local Program Facilitator and Agricultural Counselor. Those parties are unlikely to have experience in real business activities both in the scope of agricultural production and in marketing agricultural production. This causes limitations in the development of institution strategies (Institution behavior) to deal with market structures, such as the ability to compose partnership proposals, networking, contract-based risk management and business negotiations, financial management to protect people from low harvest and / or increasing prices of high agricultural inputs, market contractbased strategies, production strategies through diversification, geographical distribution, selection of varieties, timeliness, drainage, use of cultivation methods that are most suitable for certain regions, and cooperation with third parties such as insurance agencies.

Innovation culture had a positive and significant effect on the capacity of innovation. In the Knowledge Era, rural institution not only in the scope of production, but also in marketing, price management, processing of harvests, finance (capital), management of production inputs which 
are all components of business units in rural institution. On the other side, Culture of innovation and entrepreneurship in rural communities in Semarang district is likely to be low. On the other hand, farmers / groups who are accustomed to be dependant (by relying on Government funding assistance, information, knowledge and experience of the elder or agricultural counselors). Various schemes of assistance provided do not make farmers more independent; instead they tend to be more dependent on subsidies. Various assistance schemes have also been implemented ranging from subsidies of Production Facilities, Direct Capital Assistance, Farmer Business Loans, and so forth. Yet, the assistances have not produced the desired results. Indonesian farmers have a low income, still. Various assistance provided also cause farmers to become dependent and feel unable to move alone in carrying out their farming. Small-scale business actors in rural areas often lack knowledge about optimal production, post-harvest processing (agriculture, fisheries), processing and storage techniques, especially those related to high-quality products and access of open innovation. Thus, smallscale businesses in rural areas with access to extension services have more ability to adopt new technologies and invest in new market trends, such as quality certification (Asfaw et al., 2007).

Knowledge transfer had a positive and significant effect on innovation capacity. Research in recent years (Berraies, Chaher, \& Ben Yahia, 2014; Byukusenge \& Munene, 2017; Carstensen \& Ibsen, 2015; Slavković \& Babić, 2013), asserted that knowledge management has been considered as a source of competitive advantage and important factors that can positively affect performance, but study in rural innovation system is still limited. Knowledge integration facilitates sharing of experience and problem solving among innovation stakeholders unlimited to space and time. Wallace (Burke \& Ng, 2006) explains that internet technology and information have a major impact on work. The development of information and communication technologies in rural areas in
Semarang Regency Indonesia currently provides ease regarding the constraints of "space and time" which has been the determining aspect of speed and the success of rural innovation systems. As to the infrastructure, the use of information technology has reached rural areas, however accessible knowledge transferactivities have not been optimal. Innovators at the level of economic institutions in rural areas need a knowledge transfersystem that facilitates them in carrying out innovation activities, such as in: choosing innovation-based problem solving, effective technologies, applications for developing innovation proposals, reporting on the use of funds connected with stakeholders (such as : institution facilitators, government institutions, financial institutions, and insurance institutions).

The research was conducted in the rural area of Semarang Regency with characteristics of the agricultural environment, technological, social, cultural and regulatory environments that are similar to other rural areas in Indonesia and developing countries. Rural areas in general have advantages compared to urban areas, thus affecting needs of innovation systems characteristic in both regions (Brillyanes \& Wilopo, 2018; Kusharsanto \& Handayani, 2017; Pyburn \& Woodhill, 2014; Santos \& Simões, 2014). In the knowledge era, rural areas have the potentials to develop innovation in a green economy based, such as the concept: sustainable agriculture (combining agricultural-livestockenergy activities), villatech, green mart, ecotourism, and community-based management in water management. Agricultural activities in rural areas provide space for physical activity, supply of fresh vegetables, fresh fruit, fresh fish, natural food. Livestock activities in rural areas in addition to providing food source supply as well as the potential for natural fertilizer and renewable energy. Agricultural land in rural areas provides food supplies to play a strategic role in the creation of food security, social security and national security. 


\section{Conclusions}

Generally, the results of the study found that the Innovation Capacity had a positive and significant impact on Institution performance. The factors influencing the capacity of Institution innovationinruralareas werepolicy and regulation, innovation infrastructure, management capacity, facilitator capacity, innovation culture and knowledge transfer. An important factors in the development of innovation systems in rural areas is Rural Innovation Infrastructure, followed by Innovation culture, Knowledge transfer, Policy and Regulation and Management capacity. The foundings of this study are the characteristics of innovation systems in rural areas which are influenced mainly by the needs of innovation infrastructure, cultural and knowledge transfer. The results of this study have implications for the role of infrastructure innovation (technology, open innovation, financial resources and networking), cultural and knowledge transfer in supporting innovation activities in rural areas.

The above founding has practical implications. Managerial of rural institutions generally have low management and innovation capacity, so the government needs to develop innovation infrastructure such as applications (technology, finance, marketing, networking) that make it easier for management actors to make decision-making, administrative, management and innovation activities. This infrastructurs making it easier for innovators, such as in: choosing innovation-based problem solving, effective technologies, applications for developing innovation proposals, reporting on the use of funds connected with stakeholders (such as: institution facilitators, government institutions, financial institutions, and insurance institutions). In addition, innovative infrastructure support can be also significantly lower transaction costs and improve access to innovation activity. Increased Innovation Infrastructure, Innovation culture, Knowledge transfereach will effectively increase innovation capacity.

This study has several limitations. First, this study uses a cross-sectional design approach through determinant analysis. Cross-sectional design based on a qualitative survey of rural managers' experience and preferences. Crosssectional design causes research to be unable to explain the influence of serial time, such as changes in policy, technology and dynamics of the social-economic environment. Second, research was conducted in Semarang Regency, with homogeneous regulatory, geographical, social and cultural conditions. Research can produce different results with different regional characteristics (regulation, agricultural, economic, social, technological). This study provides recommendations for future research, for research in other countries, other periods with different regulatory conditions, agricultural environment, economy, social, technology.

\section{Acknowledgement}

The authors thank the Research and Community Service Institute of UNDARIS University who helpful this study and reviews on an earlier version of this manuscript.

\section{References}

Asfaw, S., Mithöfer, D., Waibel, H., Asfaw, S., Mithöfer, D., \& Waibel, H. (2007). Having on Developing Countries Export of High-Value Horticultural Products? Evidence from Kenya What Impact Are EU Supermarket Standards Having on Developing Countries Export of High-Value Horticultural Products? Evidence from Kenya. Journal of International Food and Agribusiness Marketing, 22, 252-276.

Asheim, B. T., Smith, H. L., \& Oughton, C. (2011). Regional Innovation Systems: Theory, Empirics and Policy Regional Innovation Systems: Theory, Empirics and Policy. Regional Studies, 45(7), 875-891. https:// doi.org/10.1080/00343404.2011.596701

Bappeda. (2018). Konteks Kebijakan Dan Tantangan Penguatan Sida Provinsi Jawa Tengah. Semarang.

Barrett, C. B. (2008). Smallholder market 
participation : Concepts and evidence from eastern and southern Africa q. Food Policy, 33, 299-317. https://doi.org/10.1016/j. foodpol.2007.10.005

Berraies, R., Chaher, M., \& Ben Yahia, K. (2014). Knowledge Management Enablers , Knowledge Creation Process and Innovation Performance: An Empirical Study in Tunisian Information and Communication Technologies Sector. Business Management and Strategy, 5(1), 1-26. https://doi. org/10.5296/bms.v5i1.5465

BPPT. (2013). Naskah Akademik Buku Putih Penguatan Sistem Inovasi Nasional. Jakarta: Deputi Bidang Pengkajian Kebijakan Teknologi Badan Pengkajian dan Penerapan Teknologi.

BPS. (2016). Kabupaten Semarang dalam Angka 2016. Semarang: Badan Pusat Statistik Kabupaten Semarang.

Brillyanes, \& Wilopo. (2018). Regional Innovation System in Rural Areas and The Role of SMEs as Countermeasure for Poverty: A Case in East Java, Indonesia. (June 2017). https://doi.org/10.18551/rjoas.2017-06.25

Budiarto, M. S., \& Bachrudin, D. T. (2018). Barrier on Strengthening Regional Innovation System ( RIS ) in Banten Province , Indonesia. The 2018 International Conference of Organizational Innovation, KnE Social Sciences, 2018, 497-504. https:// doi.org/10.18502/kss.v3i10.3398

Burke, R. J., \& Ng, E. (2006). The changing nature of work and organizations: Implications for human resource management. Human Resource Management Review, 16, 86-94. https://doi.org/10.1016/j.hrmr.2006.03.006

Byukusenge, E., \& Munene, J. C. (2017). Knowledge management and business performance: Does innovation matter? Cogent Business \& Management, 70(1), 1-18. https://doi.org/10.1080/23311975.201 7.1368434
Carstensen, M. B., \& Ibsen, C. L. (2015). Barriers to and triggers of policy innovationand knowledge transfer in Denmark. In Policy transfer and comparativef rameworks.

Croitoru, A. (2012). Schumpeter , J . A., 1934 ( 2008 ), The Theory of Economic Development: An Inquiry into Profits, Capital, Credit, Interest and the Business Cycle. Journal Of Comparative Research In Anthropology And Sociology, 3(2), 137-148.

Kurniati, E. D. (2013). Analysis of the rural farmer entrepreneurship in non- agricultural sector Semarang Regency ( Central Java Province - Indonesia ): Case study. International Journal of Agricultural Economics and Extension, 1(1), 1-9.

Kurniati, E. D., Dian, S., \& Prajanti, W. (2018). Batik SMEs Efficiency and Entrepreneurship Role in Innovation. Jejak, 11(13), 375-389.

Kusharsanto, Z. S., \& Handayani, W. (2017). Regional Innovation System Performance in Indonesia: Case of Semarang and Balikpapan. The Asian Journal of Technology Management, 10(2), 58-73.

Pyburn, R., \& Woodhill, J. (2014). Dynamics of Rural Innovation. Arnhem: LM Publishers.

Royer, A., Bijman, J., \& Bitzer, V. (2016). Linking smallholder farmers to high quality food chains:Quality and innovation in food chains. In . https://doi.org/10.3920/978-908686-825-4

Santos, D., \& Simões, M. J. (2014). Regional innovation systems in Portugal : a critical evaluation. Investigaciones Regionales, 28, $37-56$.

Slavković, M., \& Babić, V. (2013). Knowledge Management, Innovativeness, And Organizational Performance: Evidence From Serbia. Economic Annals, LVIII(199), 85-108.

Stuetzer, M. (2017). Schumpeter , Kirzner , Knight , Simon and others : Behavioral economics 
Avalaible online at http://journals.ums.ac.id, Permalink/DOI: 10.23917/jep.v20i1.7040

Jurnal Ekonomi Pembangunan: Kajian Masalah Ekonomi dan Pembangunan, 20 (1), 2019, 108-129

and entrepreneurship. (November).

Sumpeno et al. (2013). ModulPelatihan Percepatan Program Inovasi Desa Tenaga Ahli P3MD. Kementerian Desa, Pembangunan Daerah Tertinggal, Dan Transmigrasi Republik Indonesia.

Verheul, I., \& Thurik, R. (2001). An Eclectic Theory of Entrepreneurship. Small Business Economics.
Williamson, O. (2015). The New Institutional Economics: Take Stock, Looking Ahead - The New Institutional Economics : Taking Stock, Looking Ahead. Journal of Institutional and Theoretical Economics, (November), 99-118. https://doi. org/10.1257/jel.38.3.595 


\section{Appendixes}

Appendixes 1. Endogenous and Exogenous Variables

$\mathrm{Y}=$ Institution Performance (Asset accumulation, \%), INOV= Innovation Capacity, REG= Policy and Regulation, INF= Innovation Infrastructure, MAN=Institution Capacity, CUL = Innovation Culture, KM = Capacity of Knowledge Managemen.Variables of INOV, REG, INF, MAN, CUL, KNOW are measured from the average of indicator scores (Tabel 1).

\begin{tabular}{|c|c|c|c|c|c|c|c|c|c|c|c|}
\hline \multirow{2}{*}{ No. } & \multirow{2}{*}{$\begin{array}{c}\text { Institution } \\
\text { Code }\end{array}$} & \multicolumn{7}{|c|}{ Variables } & \multicolumn{3}{|c|}{ Error } \\
\hline & & Y1 & INOV & REG & INF & MAN & CUL & KNOW & $\mathbf{u}$ & $\mathrm{u} 2$ & $\operatorname{Ln}(\mathrm{u} 2)$ \\
\hline 1 & L001 & 0.15 & 1.0 & 2.0 & 1.0 & 2.0 & 1.3 & 2.0 & 0.16 & 0.03 & -3.67 \\
\hline 2 & L002 & 0.16 & 1.0 & 1.7 & 2.0 & 2.0 & 1.3 & 2.0 & -0.10 & 0.01 & -4.52 \\
\hline 3 & L003 & 0.84 & 2.0 & 2.7 & 2.2 & 3.0 & 1.3 & 2.0 & 0.49 & 0.24 & -1.43 \\
\hline 4 & L004 & 0.18 & 1.0 & 1.7 & 1.0 & 1.7 & 1.3 & 2.0 & 0.26 & 0.07 & -2.68 \\
\hline 5 & L005 & 0.29 & 1.0 & 1.7 & 1.0 & 2.0 & 1.3 & 2.0 & 0.23 & 0.05 & -2.95 \\
\hline 6 & L006 & 0.14 & 1.0 & 1.7 & 1.0 & 2.0 & 1.3 & 2.0 & 0.23 & 0.05 & -2.95 \\
\hline 7 & L007 & 0.04 & 1.0 & 1.7 & 1.0 & 3.0 & 2.3 & 1.0 & 0.11 & 0.01 & -4.44 \\
\hline 8 & L008 & 0.10 & 1.0 & 1.7 & 1.0 & 2.0 & 1.3 & 2.0 & 0.23 & 0.05 & -2.95 \\
\hline 9 & L009 & 0.13 & 1.0 & 1.7 & 1.0 & 2.0 & 1.3 & 2.0 & 0.23 & 0.05 & -2.95 \\
\hline 10 & L010 & 0.34 & 1.0 & 1.7 & 2.0 & 2.0 & 1.3 & 2.0 & -0.10 & 0.01 & -4.52 \\
\hline 11 & L011 & 0.30 & 1.0 & 1.7 & 2.0 & 2.0 & 1.3 & 1.0 & 0.15 & 0.02 & -3.75 \\
\hline 12 & L012 & 0.12 & 1.0 & 2.0 & 1.0 & 2.0 & 1.3 & 2.0 & 0.16 & 0.03 & -3.67 \\
\hline 13 & L013 & 0.59 & 1.5 & 2.7 & 2.0 & 3.0 & 2.3 & 1.0 & 0.04 & 0.00 & -6.21 \\
\hline 14 & L014 & 0.16 & 1.0 & 1.7 & 1.0 & 2.0 & 1.3 & 2.0 & 0.23 & 0.05 & -2.95 \\
\hline 15 & L015 & 0.27 & 1.0 & 1.7 & 2.0 & 2.0 & 2.3 & 1.0 & -0.11 & 0.01 & -4.33 \\
\hline 16 & L016 & 0.23 & 1.0 & 1.7 & 2.0 & 2.0 & 2.3 & 1.0 & -0.11 & 0.01 & -4.33 \\
\hline 17 & L017 & 0.43 & 1.0 & 1.7 & 2.0 & 2.0 & 1.3 & 2.0 & -0.10 & 0.01 & -4.52 \\
\hline 18 & L018 & 0.16 & 1.0 & 1.7 & 1.0 & 2.0 & 1.3 & 2.0 & 0.23 & 0.05 & -2.95 \\
\hline 19 & L019 & 0.31 & 1.0 & 1.7 & 2.0 & 2.0 & 2.3 & 1.0 & -0.11 & 0.01 & -4.33 \\
\hline 20 & L020 & 0.09 & 1.0 & 1.7 & 1.0 & 2.0 & 1.3 & 2.0 & 0.23 & 0.05 & -2.95 \\
\hline 21 & L021 & 0.52 & 1.0 & 2.7 & 2.0 & 2.0 & 1.3 & 2.0 & -0.34 & 0.11 & -2.19 \\
\hline 22 & L022 & 0.26 & 1.0 & 2.0 & 1.0 & 2.0 & 1.3 & 2.0 & 0.16 & 0.03 & -3.67 \\
\hline 23 & L023 & 1.42 & 3.0 & 2.7 & 3.0 & 2.0 & 2.3 & 2.0 & 1.06 & 1.13 & 0.12 \\
\hline 24 & L024 & 0.21 & 1.0 & 1.7 & 1.0 & 2.0 & 1.3 & 2.0 & 0.23 & 0.05 & -2.95 \\
\hline 25 & L025 & 0.32 & 1.0 & 1.7 & 2.0 & 2.0 & 1.3 & 2.0 & -0.10 & 0.01 & -4.52 \\
\hline 26 & L026 & 0.27 & 1.0 & 1.7 & 2.0 & 2.0 & 2.3 & 1.0 & -0.11 & 0.01 & -4.33 \\
\hline 27 & L027 & 0.26 & 1.0 & 1.7 & 2.0 & 2.0 & 2.3 & 1.0 & -0.11 & 0.01 & -4.33 \\
\hline 28 & L028 & 1.55 & 3.0 & 1.7 & 3.0 & 2.7 & 2.3 & 2.0 & 1.22 & 1.48 & 0.39 \\
\hline 29 & L029 & 0.54 & 1.0 & 2.7 & 2.0 & 2.0 & 1.3 & 2.0 & -0.34 & 0.11 & -2.19 \\
\hline 30 & L030 & 0.18 & 1.0 & 1.7 & 2.0 & 1.0 & 2.3 & 1.3 & -0.08 & 0.01 & -4.98 \\
\hline 31 & L031 & 0.52 & 1.0 & 1.7 & 2.0 & 1.0 & 2.3 & 1.3 & -0.08 & 0.01 & -4.98 \\
\hline 32 & L032 & 0.10 & 1.0 & 1.7 & 2.0 & 1.0 & 2.3 & 1.3 & -0.08 & 0.01 & -4.98 \\
\hline 33 & L033 & 0.25 & 1.0 & 1.7 & 2.0 & 1.0 & 2.3 & 1.3 & -0.08 & 0.01 & -4.98 \\
\hline 34 & L034 & 0.28 & 1.0 & 1.7 & 2.0 & 2.0 & 2.3 & 1.0 & -0.11 & 0.01 & -4.33 \\
\hline 35 & L035 & 0.10 & 1.0 & 1.7 & 2.0 & 1.0 & 2.3 & 1.0 & -0.01 & 0.00 & -10.38 \\
\hline 36 & L036 & 0.12 & 1.0 & 1.7 & 2.0 & 2.0 & 2.3 & 1.0 & -0.11 & 0.01 & -4.33 \\
\hline 37 & L037 & 0.10 & 1.0 & 1.7 & 2.0 & 1.0 & 2.3 & 1.0 & -0.01 & 0.00 & -10.38 \\
\hline 38 & L038 & 0.16 & 1.0 & 2.0 & 2.0 & 2.0 & 2.3 & 1.0 & -0.18 & 0.03 & -3.38 \\
\hline 39 & L039 & 1.45 & 3.0 & 1.7 & 2.2 & 1.0 & 2.3 & 1.0 & 1.93 & 3.72 & 1.31 \\
\hline 40 & L040 & 0.88 & 2.0 & 1.7 & 2.0 & 3.0 & 1.3 & 2.0 & 0.79 & 0.62 & -0.48 \\
\hline 41 & L041 & 1.13 & 2.0 & 2.7 & 3.0 & 2.0 & 2.3 & 2.0 & 0.06 & 0.00 & -5.50 \\
\hline
\end{tabular}




\begin{tabular}{|c|c|c|c|c|c|c|c|c|c|c|c|}
\hline \multirow{3}{*}{ No. } & \multirow{3}{*}{$\begin{array}{r}\text { Avalai } \\
\text { Jurnal Ekon } \\
\begin{array}{l}\text { Institution } \\
\text { Code }\end{array} \\
\end{array}$} & \multirow{3}{*}{\multicolumn{4}{|c|}{$\begin{array}{l}\text { e online at http://journals.ums.ac.id, P } \\
\text { ii Pembangunan: Kajian Masalah Ekor } \\
\\
\text { Y1 Variables } \\
\text { INOV } \quad \text { REG INF }\end{array}$}} & \multirow{3}{*}{\multicolumn{2}{|c|}{$\begin{array}{l}\text { ermalink/DOI: } 1 \\
\text { nomi dan Pembs } \\
\text { MAN CUL } \\
\end{array}$}} & \multirow{3}{*}{$\begin{array}{l}0.23917 / \mathrm{je} \\
\text { ngunan, } \\
\text { KNOW } \\
\end{array}$} & \multirow{2}{*}{\multicolumn{3}{|c|}{$\begin{array}{l}. v 20 i 1.7040 \\
(1), 2019,108-129 \\
\text { Error }\end{array}$}} \\
\hline & & & & & & & & & & & \\
\hline & & & & & & & & & $\mathbf{u}$ & $\mathrm{u} 2$ & $\operatorname{Ln}(\mathrm{u} 2)$ \\
\hline 42 & L042 & 0.06 & 1.0 & 1.7 & 2.0 & 1.0 & 2.3 & 1.0 & -0.01 & 0.00 & -10.38 \\
\hline 43 & L043 & 0.05 & 1.0 & 1.7 & 2.0 & 1.0 & 2.3 & 1.3 & -0.08 & 0.01 & -4.98 \\
\hline 44 & L044 & 0.31 & 1.0 & 1.7 & 2.0 & 1.0 & 2.3 & 1.3 & -0.08 & 0.01 & -4.98 \\
\hline 45 & L045 & 0.27 & 1.0 & 1.7 & 2.0 & 2.0 & 1.3 & 2.0 & -0.10 & 0.01 & -4.52 \\
\hline 46 & L046 & 0.11 & 1.0 & 1.7 & 2.0 & 1.0 & 2.3 & 1.0 & -0.01 & 0.00 & -10.38 \\
\hline 47 & L047 & 0.38 & 1.0 & 1.7 & 2.0 & 1.0 & 2.3 & 1.0 & -0.01 & 0.00 & -10.38 \\
\hline 48 & L048 & 0.04 & 1.0 & 1.7 & 2.0 & 1.0 & 2.3 & 2.0 & -0.26 & 0.07 & -2.67 \\
\hline 49 & L049 & 0.37 & 1.0 & 1.7 & 2.0 & 1.0 & 2.3 & 1.3 & -0.08 & 0.01 & -4.98 \\
\hline 50 & L050 & 0.09 & 1.0 & 1.7 & 2.0 & 1.0 & 2.3 & 1.0 & -0.01 & 0.00 & -10.38 \\
\hline 51 & L051 & 0.08 & 1.0 & 1.7 & 2.0 & 1.0 & 2.3 & 1.3 & -0.08 & 0.01 & -4.98 \\
\hline 52 & L052 & 0.19 & 1.0 & 1.7 & 2.0 & 1.0 & 2.3 & 1.3 & -0.08 & 0.01 & -4.98 \\
\hline 53 & L053 & 0.03 & 1.0 & 1.7 & 2.0 & 1.0 & 2.3 & 1.0 & -0.01 & 0.00 & -10.38 \\
\hline 54 & L054 & 0.09 & 1.0 & 1.7 & 2.0 & 1.0 & 2.3 & 1.0 & -0.01 & 0.00 & -10.38 \\
\hline 55 & L055 & 0.18 & 1.0 & 1.7 & 2.0 & 1.0 & 2.3 & 1.0 & -0.01 & 0.00 & -10.38 \\
\hline 56 & L056 & 0.04 & 1.0 & 1.7 & 2.0 & 1.0 & 2.3 & 1.0 & -0.01 & 0.00 & -10.38 \\
\hline 57 & L057 & 0.25 & 1.0 & 1.7 & 2.0 & 1.0 & 2.3 & 1.0 & -0.01 & 0.00 & -10.38 \\
\hline 58 & L058 & 0.01 & 1.0 & 1.7 & 2.0 & 1.0 & 2.3 & 1.0 & -0.01 & 0.00 & -10.38 \\
\hline 59 & L059 & 0.47 & 1.0 & 2.7 & 2.0 & 2.0 & 1.3 & 2.0 & -0.34 & 0.11 & -2.19 \\
\hline 60 & L060 & 0.11 & 1.0 & 1.7 & 2.0 & 1.0 & 2.3 & 1.0 & -0.01 & 0.00 & -10.38 \\
\hline 61 & L061 & 0.13 & 1.0 & 1.7 & 2.0 & 1.0 & 2.3 & 1.0 & -0.01 & 0.00 & -10.38 \\
\hline 62 & L062 & 0.53 & 1.0 & 2.7 & 2.0 & 2.0 & 1.3 & 2.0 & -0.34 & 0.11 & -2.19 \\
\hline 63 & L063 & 0.53 & 1.0 & 2.7 & 2.0 & 2.0 & 1.3 & 2.0 & -0.34 & 0.11 & -2.19 \\
\hline 64 & L064 & 0.50 & 1.0 & 1.7 & 2.0 & 3.0 & 2.3 & 2.0 & -0.48 & 0.23 & -1.46 \\
\hline 65 & L065 & 0.39 & 1.0 & 2.7 & 2.0 & 2.0 & 2.3 & 2.0 & -0.60 & 0.36 & -1.01 \\
\hline 66 & L066 & 0.39 & 1.0 & 1.7 & 2.0 & 1.0 & 2.3 & 1.0 & -0.01 & 0.00 & -10.38 \\
\hline 67 & L067 & 0.69 & 2.0 & 2.7 & 3.0 & 1.0 & 1.3 & 2.0 & 0.44 & 0.19 & -1.64 \\
\hline 68 & L068 & 0.48 & 1.0 & 2.7 & 2.0 & 2.0 & 1.3 & 2.0 & -0.34 & 0.11 & -2.19 \\
\hline 69 & L069 & 0.10 & 1.0 & 1.7 & 2.0 & 1.0 & 2.3 & 1.3 & -0.08 & 0.01 & -4.98 \\
\hline 70 & L070 & 0.15 & 1.0 & 1.7 & 2.0 & 1.0 & 2.3 & 1.0 & -0.01 & 0.00 & -10.38 \\
\hline 71 & L071 & 0.12 & 1.0 & 1.7 & 2.0 & 2.0 & 3.0 & 1.0 & -0.30 & 0.09 & -2.39 \\
\hline 72 & L072 & 0.12 & 1.0 & 1.7 & 2.0 & 1.0 & 2.3 & 1.3 & -0.08 & 0.01 & -4.98 \\
\hline 73 & L073 & 0.66 & 2.0 & 2.7 & 2.0 & 2.0 & 2.3 & 2.0 & 0.40 & 0.16 & -1.85 \\
\hline 74 & L074 & 1.13 & 2.0 & 2.7 & 3.0 & 2.0 & 2.3 & 2.0 & 0.06 & 0.00 & -5.50 \\
\hline 75 & L075 & 0.71 & 2.0 & 2.7 & 2.2 & 2.0 & 2.3 & 2.0 & 0.33 & 0.11 & -2.22 \\
\hline 76 & L076 & 0.36 & 1.0 & 1.7 & 2.0 & 2.0 & 2.3 & 2.0 & -0.37 & 0.14 & -1.98 \\
\hline 77 & L077 & 0.23 & 1.0 & 1.7 & 2.0 & 2.0 & 3.0 & 1.0 & -0.30 & 0.09 & -2.39 \\
\hline 78 & L078 & 0.23 & 1.0 & 1.7 & 2.0 & 2.0 & 2.3 & 2.0 & -0.37 & 0.14 & -1.98 \\
\hline 79 & L079 & 0.59 & 2.0 & 2.7 & 2.0 & 2.0 & 2.3 & 2.0 & 0.40 & 0.16 & -1.85 \\
\hline 80 & L080 & 0.61 & 2.0 & 1.7 & 2.0 & 2.0 & 2.3 & 2.0 & 0.63 & 0.39 & -0.93 \\
\hline 81 & L081 & 0.26 & 1.0 & 1.7 & 2.0 & 2.0 & 1.3 & 2.0 & -0.10 & 0.01 & -4.52 \\
\hline 82 & L082 & 0.97 & 2.0 & 2.7 & 3.0 & 1.0 & 2.3 & 1.0 & 0.43 & 0.19 & -1.68 \\
\hline 83 & L083 & 0.28 & 1.0 & 1.7 & 1.0 & 2.0 & 3.0 & 2.0 & -0.23 & 0.05 & -2.96 \\
\hline 84 & L084 & 0.45 & 1.0 & 2.7 & 2.0 & 3.0 & 2.3 & 2.0 & -0.71 & 0.51 & -0.68 \\
\hline 85 & L085 & 0.25 & 1.0 & 1.7 & 2.0 & 2.0 & 2.3 & 2.0 & -0.37 & 0.14 & -1.98 \\
\hline 86 & L086 & 0.55 & 1.0 & 1.7 & 3.0 & 3.0 & 1.3 & 2.0 & -0.55 & 0.30 & -1.21 \\
\hline 87 & L087 & 0.67 & 2.0 & 1.7 & 2.0 & 2.0 & 2.3 & 1.0 & 0.89 & 0.78 & -0.24 \\
\hline 88 & L088 & 0.21 & 1.0 & 1.7 & 2.0 & 2.0 & 1.3 & 2.0 & -0.10 & 0.01 & -4.52 \\
\hline 89 & L089 & 0.86 & 2.0 & 2.7 & 3.0 & 2.0 & 2.3 & 2.0 & 0.06 & 0.00 & -5.50 \\
\hline 90 & L090 & 0.42 & 1.0 & 2.7 & 3.0 & 1.0 & 1.3 & 2.0 & -0.56 & 0.31 & -1.16 \\
\hline & Jurn & Ekon & emba & gunar & ISS & 1411 & 081 , & -ISSN & $160-9$ & & 125 \\
\hline
\end{tabular}


Avalaible online at http://journals.ums.ac.id, Permalink/DOI: 10.23917/jep.v20i1.7040

Jurnal Ekonomi Pembangunan: Kajian Masalah Ekonomi dan Pembangunan, 20 (1), 2019, 108-129

\begin{tabular}{|c|c|c|c|c|c|c|c|c|c|c|c|}
\hline \multirow{2}{*}{ No. } & \multirow{2}{*}{$\begin{array}{c}\text { Institution } \\
\text { Code }\end{array}$} & \multicolumn{7}{|c|}{ Variables } & \multicolumn{3}{|c|}{ Error } \\
\hline & & Y1 & INOV & REG & INF & MAN & CUL & KNOW & $\mathbf{u}$ & $\mathrm{u} 2$ & $\operatorname{Ln}(\mathrm{u} 2)$ \\
\hline 91 & L091 & 0.37 & 1.0 & 1.7 & 2.0 & 3.0 & 2.3 & 2.0 & -0.48 & 0.23 & -1.46 \\
\hline 92 & L092 & 1.71 & 3.0 & 2.7 & 3.0 & 3.0 & 2.3 & 2.0 & 0.95 & 0.91 & -0.09 \\
\hline 93 & L093 & 0.28 & 1.0 & 1.7 & 2.0 & 2.0 & 1.3 & 2.0 & -0.10 & 0.01 & -4.52 \\
\hline 94 & L094 & 1.11 & 2.0 & 2.7 & 3.0 & 2.0 & 1.3 & 2.0 & 0.33 & 0.11 & -2.20 \\
\hline 95 & L095 & 0.72 & 2.0 & 2.7 & 3.0 & 2.0 & 2.3 & 2.0 & 0.06 & 0.00 & -5.50 \\
\hline 96 & L096 & 0.50 & 1.0 & 2.7 & 3.0 & 1.0 & 1.3 & 2.0 & -0.56 & 0.31 & -1.16 \\
\hline 97 & L097 & 0.73 & 2.0 & 2.7 & 3.0 & 3.0 & 2.3 & 1.3 & 0.13 & 0.02 & -4.01 \\
\hline 98 & L098 & 0.25 & 1.0 & 1.7 & 2.0 & 3.0 & 2.3 & 1.0 & -0.22 & 0.05 & -2.99 \\
\hline 99 & L099 & 0.27 & 1.0 & 1.7 & 2.0 & 3.0 & 1.3 & 1.0 & 0.04 & 0.00 & -6.24 \\
\hline 100 & L100 & 0.15 & 1.0 & 1.7 & 2.0 & 2.0 & 1.3 & 2.0 & -0.10 & 0.01 & -4.52 \\
\hline 101 & L101 & 0.33 & 1.0 & 2.7 & 3.0 & 1.0 & 1.3 & 2.0 & -0.56 & 0.31 & -1.16 \\
\hline 102 & L102 & 0.15 & 1.0 & 1.7 & 2.0 & 3.0 & 2.3 & 1.0 & -0.22 & 0.05 & -2.99 \\
\hline 103 & L103 & 0.25 & 1.0 & 1.7 & 2.0 & 2.0 & 1.3 & 2.0 & -0.10 & 0.01 & -4.52 \\
\hline 104 & L104 & 0.35 & 1.0 & 2.7 & 3.0 & 1.0 & 1.3 & 2.0 & -0.56 & 0.31 & -1.16 \\
\hline 105 & L105 & 0.25 & 1.0 & 1.7 & 2.0 & 3.0 & 1.3 & 1.0 & 0.04 & 0.00 & -6.24 \\
\hline 106 & L106 & 0.20 & 1.0 & 1.7 & 2.0 & 3.0 & 2.3 & 1.0 & -0.22 & 0.05 & -2.99 \\
\hline 107 & L107 & 0.11 & 1.0 & 1.7 & 2.0 & 3.0 & 2.3 & 1.0 & -0.22 & 0.05 & -2.99 \\
\hline 108 & L108 & 0.13 & 1.0 & 1.0 & 1.0 & 3.0 & 3.0 & 2.0 & -0.18 & 0.03 & -3.48 \\
\hline 109 & L109 & 0.27 & 1.0 & 2.0 & 1.0 & 1.0 & 1.3 & 2.0 & 0.27 & 0.07 & -2.63 \\
\hline 110 & L110 & 0.26 & 1.0 & 1.7 & 2.0 & 3.0 & 2.3 & 1.0 & -0.22 & 0.05 & -2.99 \\
\hline 111 & L111 & 0.08 & 1.0 & 1.7 & 2.2 & 3.0 & 2.3 & 1.0 & -0.29 & 0.08 & -2.47 \\
\hline
\end{tabular}

\section{Appendixes 2. Regression Result}

$\mathrm{Y}=$ Institution Performance (Asset accumulation, \%), INOV= Innovation Capacity, REG= Policy and Regulation, INF= Innovation Infrastructure, MAN=Institution Capacity, CUL = Innovation Culture, KM = Capacity of Knowledge Managemen.

MODEL 1

\begin{tabular}{lcccc}
\hline \multicolumn{5}{c}{ Model Summary } \\
\hline Model & $\mathbf{R}$ & R Square & $\begin{array}{c}\text { Adjusted R } \\
\text { Square }\end{array}$ & $\begin{array}{c}\text { Std. Error of the } \\
\text { Estimate }\end{array}$ \\
\hline 1 & $.893^{\text {a }}$ & .797 & .795 & .14998 \\
\hline a. Predictors: (Constant), INOV & &
\end{tabular}

\begin{tabular}{clccccc}
\hline \multicolumn{1}{c}{} & \multicolumn{7}{c}{ ANOVA $^{\mathbf{b}}$} \\
\hline \multirow{4}{*}{1} & Model & Sum of Squares & df & Mean Square & F & Sig. \\
\hline & Regression & 9.620 & 1 & 9.620 & 427.692 & $.000^{\mathrm{a}}$ \\
& Residual & 2.452 & 109 & .022 & & \\
& Total & 12.072 & 110 & & & \\
\hline
\end{tabular}

a. Predictors: (Constant), INOV

b. Dependent Variable: Y 
Avalaible online at http://journals.ums.ac.id, Permalink/DOI: 10.23917/jep.v20i1.7040

Jurnal Ekonomi Pembangunan: Kajian Masalah Ekonomi dan Pembangunan, 20 (1), 2019, 108-129

\begin{tabular}{|c|c|c|c|c|c|c|}
\hline \multicolumn{7}{|c|}{ Coefficients $^{\mathrm{a}}$} \\
\hline & \multirow{2}{*}{$\begin{array}{c}\text { Model } \\
\text { B }\end{array}$} & \multicolumn{2}{|c|}{ Unstandardized Coefficients } & \multirow{2}{*}{$\begin{array}{c}\text { Standardized } \\
\text { Coefficients }\end{array}$} & \multirow{2}{*}{$\mathrm{t}$} & \multirow{2}{*}{ Sig } \\
\hline & & Std. Error & Beta & & & \\
\hline \multirow{2}{*}{1} & (Constant) & -.363 & .038 & & -9.500 & .000 \\
\hline & INOV & .605 & .029 & .893 & 20.681 & .000 \\
\hline
\end{tabular}

a. Dependent Variable: Y1

MODEL 2

\begin{tabular}{cccccc}
\hline \multicolumn{5}{c}{ Model Summary $^{\mathrm{b}}$} \\
\hline Model & $\mathbf{R}$ & R Square & $\begin{array}{c}\text { Adjusted R } \\
\text { Square }\end{array}$ & $\begin{array}{c}\text { Std. Error of the } \\
\text { Estimate }\end{array}$ & Durbin-Watson \\
\hline 1 & $.630^{\mathrm{a}}$ & .396 & .368 & .38862 & 1.795 \\
\hline
\end{tabular}

a. Predictors: (Constant), KNOW, INF, MAN, CUL, REG

b. Dependent Variable: INOV

\begin{tabular}{clccccc}
\hline \multicolumn{7}{c}{ ANOVA $^{\mathbf{b}}$} \\
\hline \multirow{4}{*}{1} & Model & Sum of Squares & df & Mean Square & F & Sig. \\
\hline & Regression & 10.417 & 5 & 2.083 & 13.796 & $.000^{\text {a }}$ \\
& Residual & 15.857 & 105 & .151 & & \\
& Total & 26.275 & 110 & & & \\
\hline
\end{tabular}

a. Predictors: (Constant), KNOW, INF, MAN, CUL, REG

b. Dependent Variable: INOV

\begin{tabular}{|c|c|c|c|c|c|c|c|c|}
\hline \multicolumn{9}{|c|}{ Coefficients $^{a}$} \\
\hline & \multirow[t]{2}{*}{ Model } & \multicolumn{2}{|c|}{$\begin{array}{l}\text { Unstandardized } \\
\text { Coefficients }\end{array}$} & \multirow{2}{*}{$\begin{array}{c}\begin{array}{c}\text { Standardized } \\
\text { Coefficients }\end{array} \\
\text { Beta }\end{array}$} & \multirow[t]{2}{*}{$\mathbf{t}$} & \multirow[t]{2}{*}{ Sig. } & \multicolumn{2}{|c|}{$\begin{array}{l}\text { Collinearity } \\
\text { Statistics }\end{array}$} \\
\hline & & B & Std. Error & & & & Tolerance & VIF \\
\hline \multirow{6}{*}{1} & (Constant) & -1.036 & .315 & & -3.288 & .001 & & \\
\hline & REG & .231 & .115 & .206 & 2.010 & .047 & .545 & 1.834 \\
\hline & INF & .333 & .086 & .368 & 3.851 & .000 & .629 & 1.590 \\
\hline & MAN & .109 & .055 & .155 & 1.997 & .048 & .949 & 1.054 \\
\hline & CUL & .268 & .087 & .286 & 3.080 & .003 & .667 & 1.498 \\
\hline & KNOW & .258 & .103 & .250 & 2.490 & .014 & .570 & 1.754 \\
\hline
\end{tabular}

a. Dependent Variable: INOV 


\section{Normal Distribution Tests}

\begin{tabular}{llr}
\hline \multicolumn{2}{c}{ One-Sample Kolmogorov-Smirnov Test } \\
\hline $\mathrm{N}$ & & $\begin{array}{c}\text { Unstandardized } \\
\text { Residual }\end{array}$ \\
\hline \multirow{2}{*}{ Normal Parameters ${ }^{\mathrm{a}}$} & Mean & 111 \\
& Std. Deviation & .0000000 \\
& Absolute & .37968235 \\
Most Extreme Differences & Positive & .173 \\
& Negative & .173 \\
Kolmogorov-Smirnov Z & & -.111 \\
Asymp. Sig. (2-tailed) & & 2.818 \\
\hline a. Test distribution is Normal. & .083 \\
\hline
\end{tabular}

\section{Auticorelation Tests}

\begin{tabular}{lr}
\hline \multicolumn{2}{c}{ Runs Test } \\
\hline & $\begin{array}{c}\text { Unstandardized } \\
\text { Residual }\end{array}$ \\
\hline Test Value $^{\mathrm{a}}$ & -.08283 \\
Cases $<$ Test Value & 47 \\
Cases >= Test Value & 64 \\
Total Cases & 111 \\
Number of Runs & 54 \\
Z & -.234 \\
Asymp. Sig. (2-tailed) & .815 \\
\hline a. Median
\end{tabular}

Heterocedasticity

\begin{tabular}{|c|c|c|c|c|c|c|}
\hline \multicolumn{7}{|c|}{ ANOVA $^{b}$} \\
\hline & Model & Sum of Squares & df & Mean Square & $\mathbf{F}$ & Sig. \\
\hline \multirow{3}{*}{1} & Regression & 1.290 & 5 & .258 & 1.583 & $.171^{\mathrm{a}}$ \\
\hline & Residual & 17.121 & 105 & .163 & & \\
\hline & Total & 18.411 & 110 & & & \\
\hline
\end{tabular}

a. Predictors: (Constant), KNOW, INF, MAN, CUL, REG

b. Dependent Variable: u2 
Avalaible online at http://journals.ums.ac.id, Permalink/DOI: 10.23917/jep.v20i1.7040

Jurnal Ekonomi Pembangunan: Kajian Masalah Ekonomi dan Pembangunan, 20 (1), 2019, 108-129

\begin{tabular}{|c|c|c|c|c|c|c|}
\hline \multicolumn{7}{|c|}{ Coefficients $^{\mathrm{a}}$} \\
\hline & \multirow{2}{*}{ Model } & \multicolumn{2}{|c|}{ Unstandardized Coefficients } & \multirow{2}{*}{$\begin{array}{c}\begin{array}{c}\text { Standardized } \\
\text { Coefficients }\end{array} \\
\text { Beta } \\
\end{array}$} & \multirow{2}{*}{$\mathbf{t}$} & \multirow{2}{*}{ Sig. } \\
\hline & & B & Std. Error & & & \\
\hline \multirow{6}{*}{1} & (Constant) & -.511 & .328 & & -1.559 & .122 \\
\hline & REG & -.070 & .119 & -.075 & -.585 & .560 \\
\hline & INF & .197 & .090 & .261 & 1.199 & .130 \\
\hline & MAN & .023 & .057 & .039 & .404 & .687 \\
\hline & CUL & .076 & .091 & .096 & .834 & .406 \\
\hline & KNOW & .130 & .107 & .151 & 1.209 & .229 \\
\hline
\end{tabular}

a. Dependent Variable: u2 